\title{
The analysis of students' mathematical representation errors in solving word problem related to graph
}

\author{
Rahmah Johar $^{1}$, Khairiyah Rahma Lubis ${ }^{1}$ \\ ${ }^{1}$ Department of Mathematics Education, Universitas Syiah Kuala. \\ Jalan Teuku Nyak Arief, Darussalam, Banda Aceh, Aceh, 23111, Indonesia \\ * Corresponding Author. Email: rahmah.johar@unsyiah.ac.id \\ Received: 9 December 2017; Revised: 9 March 2018; Accepted: 27 April 2018
}

\begin{abstract}
The skills of reading, interpreting and constructing graphs are important for students. These skills are related to mathematical representation. The purpose of this study is to analyze Grade 8 students' representation errors in solving word problems related to graphs in one of junior high schools in Banda Aceh, Indonesia. The data were obtained based on a mathematics test administered to 36 students and a short interview conducted for five selected students. The test consisted of eight problems adapted from four contexts of PISA problems related to graph. Students' representation errors were classified based on the errors of changing one representation to another representation, such as visual to verbal, visual to symbolic, visual to visual and verbal to visual. The results reveal that representation errors are not solely influenced by the types of representation. It is indicated by the questions with similar representation resulted in a different percentage of students committing representation errors. In general, the students' representation errors are due to the fact that students not being familiar with the problems requiring representation; students not being used to solve PISA context problems and word problems; as well as the teachers' time constraint in teaching non-routine problems.
\end{abstract}

Keywords: representation error, word problem, graph

How to Cite: Johar, R., \& Lubis, K. (2018). The analysis of students' mathematical representation errors in solving word problem related to graph. Jurnal Riset Pendidikan Matematika, 5(1), 96-107. doi:http://dx.doi.org/10.21831/jrpm.v5i1.17277

Permalink/DOI: http://dx.doi.org/10.21831/jrpm.v5i1.17277

\section{INTRODUCTION}

Mathematics is the foundation of science and technology that plays an important role in developing a nation's socioeconomic and therefore it is taught at each level of education (Enu, Agyman, \& Nkum, 2015; Gegbe \& .J.M, 2015; Mbugua, Kibet, Muthaa, \& Nkonke, 2012). One of the basic competences in learning mathematics is the mathematical representation ability. Representation involves transforming a problem or idea into a new form such as the graph or physical model to the symbols, words or sentences (National Council of Teacher Mathematics, 2000).

Representation can be used by students to communicate ideas or solutions of the problems. The expression of mathematical representation in Indonesia has been listed in the purposes of mathematics learning at schools in the government regulation No.23, Year 2006 (Departemen Pendidikan Nasional, 2007).

Knuth \& Jones (1991) mentioned some reasons of why the representation ability is required, namely: (1) it is the basic ability to build mathematical concepts and thinking, (2) it is needed for a good concept understanding and can be used in problem solving. Representation is one of the configurations or forms, characters, symbols or objects which can describe, represent or symbolize the other forms (Goldin, 2002). Based on several definitions mentioned before, it can be concluded that representation is the expressions of mathematical ideas shown by students as a model transformed from a problem situation to create solutions as the results of students' thinking interpretations.

Graciella \& Suwangsih (2016) stated that there are three indicators of representation, namely: symbolic, visual and verbal representa- 
tion. Each representation can be called as representation through action, graph, word and language. This is in line with Alhadad (2010) who argued that multiple mathematics representation ability is the ability to use various mathematical forms to explain mathematical ideas, translating among mathematical forms and interpreting mathematical phenomenon with various mathematical forms including visual (graphs, tables, diagrams and pictures); symbolic (mathematical statements or notations, numeric or algebraic symbols); verbal (words or written texts).

Table, figure, graph, mathematical sentence, or combinations of all are some representations often used in communicating mathematics (Cai, Lane, \& Jakabcsin, 1996, p. 43). Cai et al. (1996) defined the visual, verbal and symbolic representation as follows: (1) Visual representation (imagistic) is the type of representation involving graph, visualized diagram; (2) Verbal representation (synthetics) is one's ability to organize natural language at the level of words, phrases and sentences; (3) Symbolic representation is the ability to formulate notations or symbols from the situation provided and to interpret the graph given.

Representation plays an important role in developing and improving students' mathematics ability. One of the major signs of conceptual understanding is the ability to use several mathematical representations for the transition process between several types of descriptions, such as graph, table, as well as algebraic and verbal expression (Kar et al., 2011). Therefore, the use of mathematical representation is crucial (Ahmad \& Nawawi, 2010).

Most students are lacking of mathematical representation ability. Some studies were carried out to investigate students' errors in conducting the representation. Legi (2009) found out that low achieving students are having difficulties in creating and using the representation of symbols and graphs. The lack of students' mathematical representation ability can also be observed based on the survey conducted by the Trends in International Mathematics and Science Study (TIMSS) 2011, in which Indonesia was ranked at the $38^{\text {th }}$ out of 42 countries (the score was 386). While, there are around $9 \%$ of TIMSS 2011 problems related to graph (8 out of 88). These facts point out the lack of Indonesian students' mathematics performance at the level of junior high school. The lack of students' mathematical representation ability is also found in the survey results conducted by OECD (2003), in which Indonesia achieved poorly in the PISA results. In PISA 2012, Indonesian students' score was 375 for mathematics ability lower than the average OECD score of 494 . Indonesia ranked at the $64^{\text {th }}$ out of 65 countries participating in PISA 2012. There are also some graphs related problems in each PISA period, approximately $27 \%$ in 2006 (3 out of 11 problems) and 20\% in 2009 (18 out of 89 problem). Therefore, it is required to analysis the types of errors committed by students in solving problems related to graphs.

Wardhani \& Rumiati (2011) argued that PISA problems demand problem solving ability. Representation and problem solving are closely related as suggested by Knuth \& Jones (1991), "empirical studies suggest that mathematics problem solving competency depends on one's ability to think in term of different representational system during problem solving process". Therefore, one's ability to consider the form of representation involved is required in problem solving. This shows that one's ability in modifying one representation to another representation will influence his/her ability in finding solution for the problem. A sophisticated problem can be simple when an accurate representation is used.

Based on the types of problems, word problems demand more representation ability. Rosyidi (2011) stated that mathematics word problems usually use verbal language and are related to daily life. Furthermore, Dewi, Suarjana, \& Sumantri (2014) mentioned that the purposes of word problems given to students are to enable students to get use to think deductively, to find the relationships and the use of mathematics in daily life and to support students in mastering mathematics ability as well as strengthening students' mathematical concepts. A mathematical word problem is defined as mathematical problems presented in a context of a story or a real-life situation (Adams, 2003). It can also be defined as mathematical task that is 'dressed up' in a real-world situation requiring students to 'undress' and solve them (Palm, 2009).

The mathematics problems used in this study are word problems related to graph adopted from PISA problems. In PISA, the process required to solve the problems related to real-life is called 'mathematization' (OECD, 2009). This process involves: understanding the 
problem in the real-life; organizing the real-life problem based on the mathematics concepts and identifying relevant mathematics; transforming the real-life problem to mathematics problem representing the situation; solving mathematics problems; and interpreting the mathematical solution in the real situation (OECD, 2009).

In general, the mathematization process in PISA is similar to the process of mathematics modeling. Students are required to have mathematics competence related to cognitive demand of context based test in order to be successful in conducting mathematization (OECD, 2009). Recognizing the cognitive demand of context based test, PISA has defined three types of tasks: First, Reproduction tasks: these tasks require re-withdrawing of mathematics object and properties, conducting routine procedures, applying standard algorithms, and implementing technical skills. Second, Connection tasks: these tasks require integration and connection of various mathematics curriculums or interconnected of various representation problems. These tasks are non-routine and demand transformation between context and mathematical world. Third, Reflection tasks: these tasks include complex situation problems in which the mathematics procedures needed are not obvious.

Teaching students to read, interpret and construct graphs is one of the important materials in junior high school curriculum, including in the topics of comparison, linear equation, linear equation with two variables, quadratic equation and statistics. Firstly, graphs can represent or shorten data. Secondly, graphs make data communication easier to be interpreted. Graphs can present a content to be real, improve the understanding of concepts and its relations to another concept, build a conceptual framework and shorten the learning materials (Kilic, Sezen, $\&$ Sari, 2012). However, the results of study conducted by Shah \& Hoeffner (2002), Kali (2005), and Kilic et al. (2012) concluded that students are lacking of abilities involving reading, interpreting, understanding and solving problems in the form of graphs.

A recent study conducted by Bunawan, Setiawan, Rusli, \& Nahadi (2015) revealed that the graph reading and interpreting skills of prospective teachers are inadequate. In addition, the skills of analyzing graph based on the types of graph and the level or question type developed are not sufficient. Students' error may be the consequences of the inappropriate knowledge and understanding during the process of receiving and organizing information from the teacher.

Detecting students' mistakes in reading, interpreting and communicating the relationships among variables in the form of graphs and constructing the graphs are required to improve the learning effectiveness. Examining students' work in mathematics test is one way to investigate the students' errors.

A study carried out by Wijaya, van den Heuvel-Panhuizen, Doorman, \& Robitzsch (2014) analyzed students' errors in solving PISA problems by classifying the errors into several types, namely: (1) understanding the problem, (2) transforming a problem to a mathematics model, and (3) conducting mathematical procedures and interpreting the obtained solution. They concluded that the percentage of students' who provide incorrect answers are higher (especially for the type 1 and 2 errors) for the problem requiring a higher cognitive demand, i.e. connection and reflection task.

Some of the problems used in this study are related to graph. Student treated a graph as a literal picture of a situation, their interpretation focused on the shape of the graph, instead of the properties of the graph (Wijaya et al., 2014). The mathematical literacy of Senior High School students in Yogyakarta is at the lowest category, in particular some students are having difficulty in understanding contextual problems (Sari \& Wijaya, 2017). Therefore, a more through investigation on students' representation error related to PISA problems consisting graph is required to examine when the representation transformation students' errors occur, whether it is in the process of transforming the verbal to visual representation or verbal to symbolic representation and vice versa.

Based on the finding of previous studies mentioned before, it is clear that the efforts should be made to describe the ability of students' mathematical representation in solving word problems related to graphs. This research is important to examine to what extent students make mistakes in graph representation. Errors in solving the word problem related to graph can be used to detect students' difficulties which in turn can be utilized to improve students' mathematics outcomes. The research problems of this study are: first, How are students' errors of mathematical representation in solving word problem related to graph? Second, what are the 


\section{Jurnal Riset Pendidikan Matematika, 5 (1), 2018 - 99}

Rahmah Johar, Khairiyah Rahma Lubis

factors influencing students' mathematical representation?

\section{METHOD}

This research employs a qualitative approach with descriptive type that aims to build meaning about a phenomenon based on the views of participants (Cresswell, 2016, p. 259). In this study, the researcher aims to investigate and describe the errors of students' mathematical representation in solving word problems related to charts and describing the factors contributing to the errors.

This research was conducted in 2017 in one of the junior high school in Banda Aceh, Indonesia, with 36 students participated in the test. Students are selected from the special class, the best class in the school based on the test result and the students' mathematics test. Some students from this class are usually chosen to represent the school in each mathematics competition. Therefore, the researchers want to describe the students' mathematical representation ability in this class. The description of students' representation ability found in this study can be useful feedbacks for the school as guidance in selecting students for mathematics competition in the future.

The instrument of this study was a test of word problems related to graph that were adopted from the PISA 2006 and 2009 problems. This is happen due to the number of questions related to graph available in those years. In addition, there was only one graph problem found in PISA 2012 and it is similar to the problem available in PISA 2009. None of the problem from PISA 2015 is used as the problems in this study. The test consisted of eight problems from four PISA contexts related to graph. The problems were multiple choice, short answer and essay. The PISA problems were translated into Bahasa Indonesia and validated by expert before the actual test was conducted. The indicators of the test item are shown on Table 1.

In addition to mathematics test, interview guide was also used. Short interviews were conducted for five students and one teacher three days after the test administered. The interview was conducted for students who committed most errors in representations to clarify the written test results. While the interview was aimed to obtain information of the factors influencing students' representation errors in solving word problem related to graph. This interview guide contains the questions that the researcher asks to reinforce the results of the data collection conducted by the test method.

The analysis of students' errors is then based on the ability of students to use several mathematical representations for the transition process among several types of descriptions, such as graph, table, as well as algebraic and verbal expression (Kar et al., 2011). Students' answers were classified based on visual, symbolic and verbal representation and therefore, the percentage of students committed errors in conducting representation of word problem related to chart was obtained.

Table 1. Problem description

\begin{tabular}{|c|c|c|c|}
\hline Context & Indicator & $\begin{array}{c}\text { Source } \\
\text { Question }\end{array}$ & $\begin{array}{c}\text { Item } \\
\text { Question }\end{array}$ \\
\hline $\begin{array}{l}\text { Concentrations of } \\
\text { Drugs }\end{array}$ & $\begin{array}{l}\text { Representing data or information from a } \\
\text { representation of graphs }\end{array}$ & PISA 2006 & $\begin{array}{l}\text { Multiple } \\
\text { Choices }\end{array}$ \\
\hline $\begin{array}{l}\text { Concentrations of } \\
\text { Drugs }\end{array}$ & Solving problems involving mathematical expression & PISA 2006 & $\begin{array}{l}\text { Multiple } \\
\text { Choices }\end{array}$ \\
\hline Driving a car & $\begin{array}{l}\text { Representing data or information from a } \\
\text { representation of graphs }\end{array}$ & PISA 2006 & Short answer \\
\hline Driving a car & Using visual representation to solve problems & PISA 2006 & Short answer \\
\hline Driving a car & Solving problems using word or written text & PISA 2006 & Essay \\
\hline Water Tank & $\begin{array}{l}\text { Representing data or information from a } \\
\text { representation of graphs }\end{array}$ & PISA 2009 & $\begin{array}{l}\text { Multiple } \\
\text { Choices }\end{array}$ \\
\hline Wind-mill & $\begin{array}{l}\text { Creating problem situation based on the data } \\
\text { representation provided }\end{array}$ & PISA 2009 & $\begin{array}{l}\text { Multiple } \\
\text { Choices }\end{array}$ \\
\hline Wind-mill & $\begin{array}{l}\text { Creating problem situation based on the data } \\
\text { representation provided }\end{array}$ & PISA 2009 & $\begin{array}{l}\text { Multiple } \\
\text { Choices }\end{array}$ \\
\hline
\end{tabular}




\section{RESULTS AND DISCUSSION}

\section{Type of Students' Mathematical Representation Errors}

Based on the students' answers of the test, the following results are obtained as presented in Table 2 .

Table 2. The percentage of students' representation errors in solving word problem related to graph

\begin{tabular}{ccc}
\hline $\begin{array}{c}\text { Item } \\
\text { Test }\end{array}$ & $\begin{array}{c}\text { Error of } \\
\text { Representation }\end{array}$ & $\begin{array}{c}\text { Number of Students } \\
\text { Who Answered } \\
\text { Incorrectly }\end{array}$ \\
\hline 1. & Visual-Verbal & $4(11.11 \%)$ \\
2. & Visual-Symbolic & $18(50 \%)$ \\
3. & Visual-Verbal & $1(02.78 \%)$ \\
4. & Visual-Verbal & $3(08.33 \%)$ \\
5. & Visual-Verbal & $15(41.67 \%)$ \\
6. & Visual-Visual & $28(77.78 \%)$ \\
7. & Verbal-Visual & $2(5.55 \%)$ \\
8. & Verbal-Visual & $25(69.44 \%)$ \\
\hline
\end{tabular}

Note:

- Visual-Verbal: the problem given in a visual representation, students were asked to provide answer in verbal representation as the interpretation of the graph.

- Visual-Symbolic: the problem given in a visual representation, students were asked to provide answer in symbolic representation as the interpretation of the graph.

- Visual-Visual: the problem given in a visual representation, students were asked to provide answer in other visual representation.

- Verbal-Visual: the problem given in a verbal representation, students were asked to provide answer in visual representation as the interpretation of the graph.

Table 2 indicates the percentage of students' representation errors in solving word problem related to graphs. The analysis of the students' errors in solving the word problem related to the graph is then presented in the following section.

Error in Changing Visual Representation to Verbal Representation

The question is seen at Figure 1 below. Students make mistakes in representing data or information from a graph which results in incorrect answers. There are four students who answered this problem incorrectly.

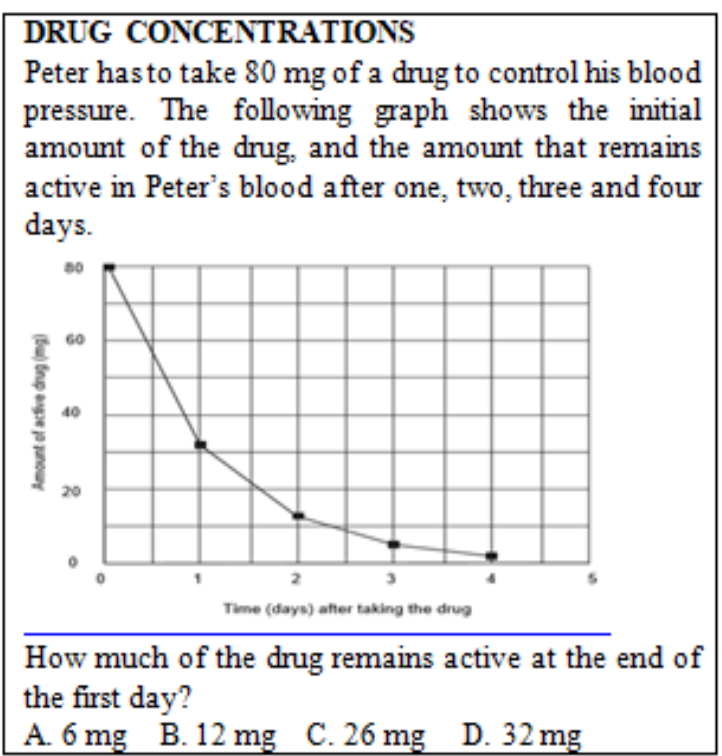

Figure 1. Item Test about Changing Visual Representation to Verbal Representation

Students' representation errors in this section occur because students have not been able to understand the information from the representation related to graph of the given problem. This agrees with the interview results of the student (SMA) who said that: "because from the graph the number of grids missing in the first day is more than 20 , so 20 is in the multiple choice, so the answer is 26 , so I choose C". SMA made mistakes in calculating the coordinate points at the vertical axis, the number of active drug at the end of the first day based on the graph is supposed to be $32 \mathrm{mg}$. Based on interview the results, it can be concluded that there are students who have not been able to read the graph well.

Error in Changing Visual to Symbolic Representation

The question at Figure 2 refers to the graph at Figure 1.

\section{DRUG CONCENTRATIONS}

From the graph for the previous question it can be seen that each day, about the same proportion of the previous day's drug remains active in Peter's blood.

At the end of each day which of the following is the approximate percentage of the previous day's drug that remains active?
A. $20 \%$
B. $30 \%$
C. $40 \%$
D. $80 \%$

Figure 2. Item Test about Changing Visual to Symbolic Representation

In this section, students made mistakes in creating the mathematical equation causing the 
error in calculating the percentage. There were 18 students provided incorrect answers for this question. Even though the problem was multiple choices, students were required to use their symbolic representation in the process of solving the problems before choosing the available option. This means that students need to change the visual to percentage. The student error in this section occurs because the student made mistakes in changing a value into percent. This is consistent with the results of interview with students (LA) who said that: "I choose D (80\%), at that time the solution was obtained by adding the number of active drugs and then divided by 100 ". The active drug concentration at the end of the second day should be divided by the amount of the active drug at the end of the first day and multiplied by $100 \%$ and therefore the correct answer is $40 \%$.

Error in Representing Data or Information of a Graph Representation

See the question as seen at Figure 3 below. In this section one student makes a mistake in representing data or information from a graph representation that lead to incorrect maximum point.

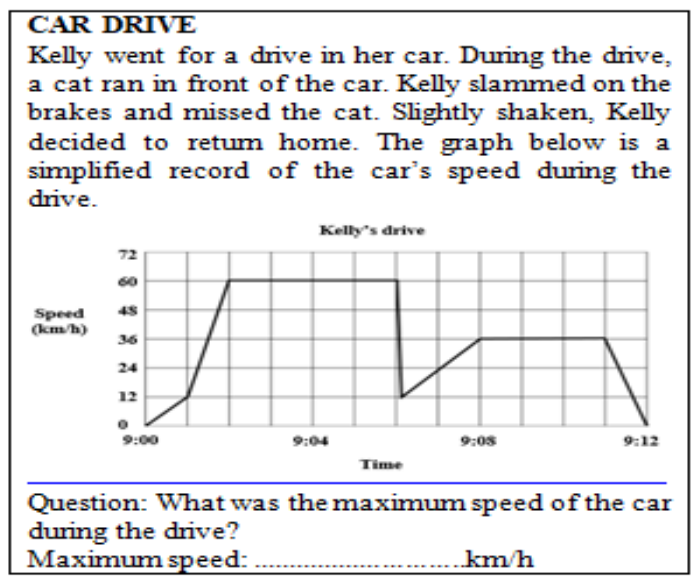

Figure 3. Item test about changing visual to verbal representation

Student error in this section occurs because student misunderstood the graph. This is in line with interview result of the student (LA) who said that: "The maximum speed can be seen when the line is going up. In the question, it is mentioned about hitting the brake, so I choose $60 \mathrm{~km} / \mathrm{hr}$ because the speed must be reduced to about $48 \mathrm{~km} / \mathrm{hr}$ ". The student was having difficulties in reasoning her/his answer. However, during the interview, the student realized his/her answer without intervention and the student answered that the maximum speed of Kelly' car is $60 \mathrm{~km} / \mathrm{h}$.

\section{Error in Changing Visual to Verbal Representation}

The question at Figure 4 refers to the graph at Figure 3. In this section, three students made mistakes in understanding the graphs resulting in incorrect minimum point.

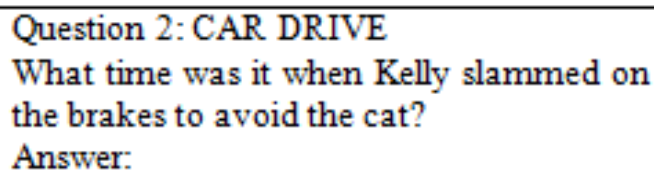

Figure 4. Item Test about Changing Visual to Verbal Representation

Students' error in this section occurred because students also misunderstood the graph. This agrees with the results of interview with student (RF) who said that: "because of looking at her/his hitting the brake, so the speed is decreasing, when I count the grids in the graph, it hit the brake at 9 o'clock past 11 '. Based on the results of the interview, it can be concluded that the students read the graph incorrectly. When Kelly pushes the brake, the speed is supposed to be minimum, so that the minimum point in the graph is showing at 09.06 o'clock.

Error in Changing Visual to Verbal Representation

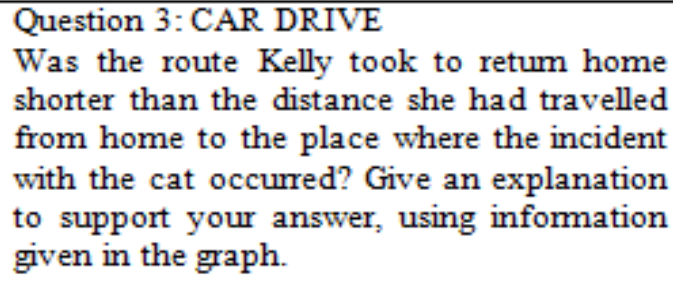

Tidak, Jarak kelly kembali ke rumah sama denganjarak varaterah ia tempun Ke lempat kejadian. Karna jarak pada grafik menumiutucan Jumlah kotakigg sama

Translation: No, the distance to return home is equal to the distance she travelled to the event place because the distance in the graph shows equal numbers of grids

Figure 5. Error in Changing Visual to Verbal Representation

The question at Figure 5 refers to the graph at Figure 3. In this section, students made a mistake in determining the distance on a graph 
leading to incorrect answer. There were 15 students provided incorrect answer in this section. Figure 5 presents one of errors in this section.

Students' errors in this section are due to the fact that students assumed that the distance was not affected by the time and speed. This is consistent with the interview results with student (HR) who said that: "because when I count the grid in the graph, it is equal number of the grids, so the distance is equal". Based on the interview result, it can be summarized that students cannot calculate the distance on the graph. The distance is not supposed to be equal as it depends on the time and speed. This means that the distance of Kelly travelling to the house is shorter than the distance of Kelly travelling to the event because of the average speed when travelling back to the house is lower than travelling from the house. Therefore, (approximately) the time spent on travelling to and from is equal.

Error in Changing Visual to Visual Representation

See the question as seen at Figure 6. In this section, the students made a mistake in choosing the appropriate picture in the question. There were 28 students answered incorrectly in this section.

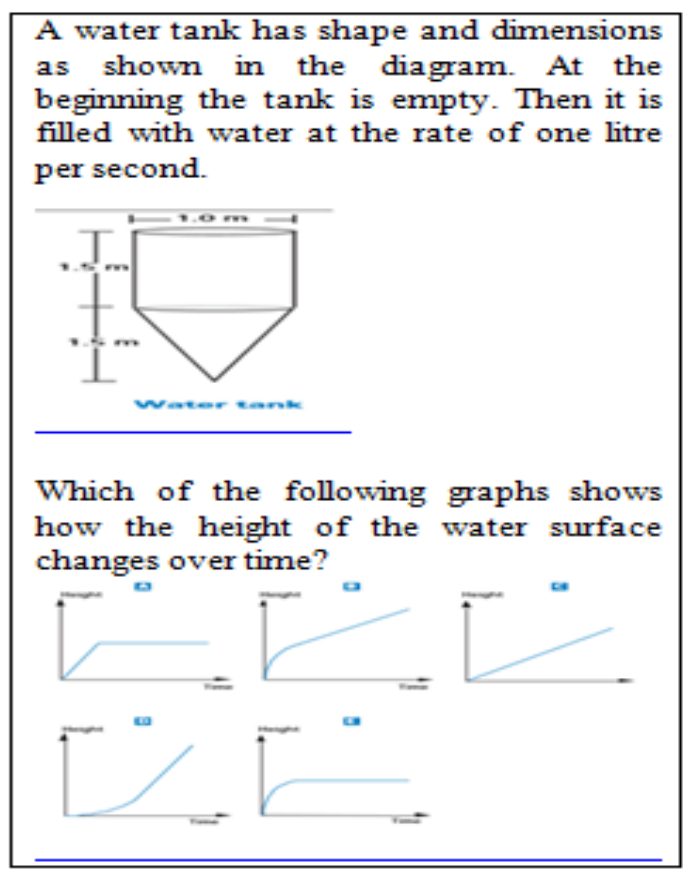

Figure 6. Item Test about Changing Visual to Visual Representation

Students' errors in this section occurred because students were not able to understand the problem well so they cannot choose which image corresponds to the instructions matter.
This is consistent with the interview results with students (FAM) who said that: "because every one second the water is increasing, so it remains the same, 1 liter". It can be concluded that students assume that the form of the container does not affect the form of the graph. Students are having difficulty in interpreting a visual representation to another visual representation. Students assumed that the unison of the form of cone and cylinder do not influence the graph. The water is supposed to increase fast (full) when it is filled into the cone, while in the cylinder, the water increases slowly. Therefore, the correct answer based on the graph illustrated is $\mathrm{B}$.

\section{Error in Changing Verbal Representation to Visual Representation}

See the question as seen at Figure 7. In this section, the students made a mistake in choosing the appropriate picture in the question. Two students answered incorrectly in this section.

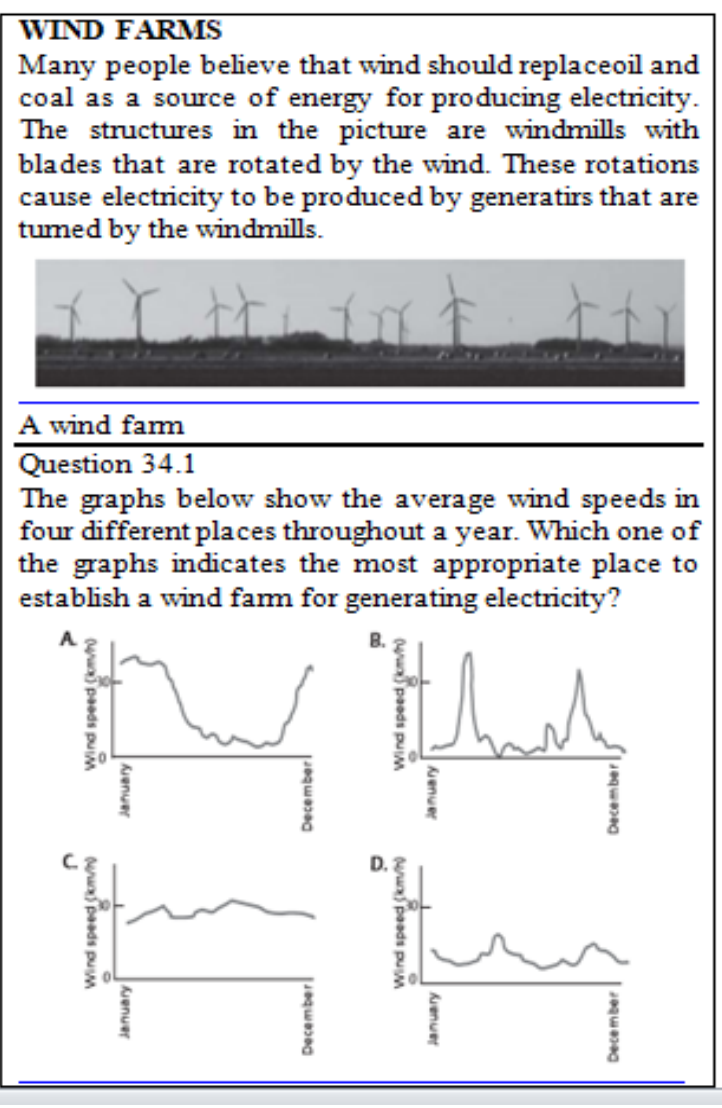

Figure 7. Item Test about Changing Verbal to Visual Representation

Students' errors in this section happened because students were not able to understand the problem well resulting in not being able to choose which image corresponds to the instruct- 


\section{Jurnal Riset Pendidikan Matematika, 5 (1), 2018 - 103}

Rahmah Johar, Khairiyah Rahma Lubis

ions matter. This is in line with the interview results with students (LA) who said: "because the wind speed is higher in the low land, so I choose D. It is suitable to build in that place, because there is much wind". Students assumed that lower place is windier compared to the higher place. It can be concluded that the students' interviewed interpreted the graph incorrectly. The most suitable place to build windmills should be the graph on the option $\mathrm{C}$.

Error in Changing Verbal to Visual Representation

The question at Figure 8 refers to the question at Figure 7. In this section, the students made a mistake in choosing the appropriate picture with the help of the question. There were 25 students presented incorrect answer in this section.

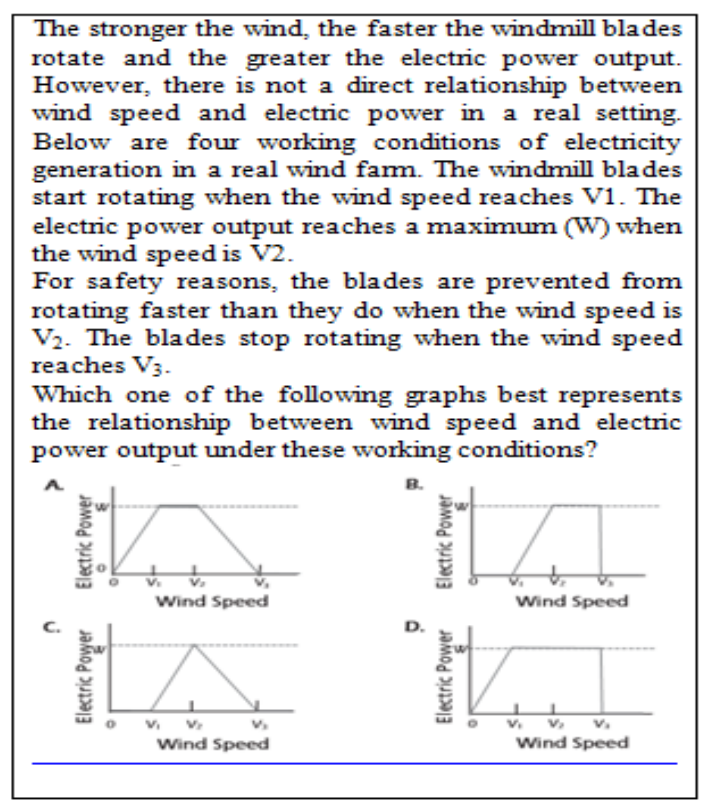

Figure 8. Item Test about Changing Verbal to Visual Representation

Students' errors in this section are due to the fact that students were not been able to understand the concept of the story given. This condition lead students make a mistake in choosing graph. This problem is classified as the hard problem as it is related to the contexts of other discipline, namely physics. Students are having difficulty in understanding the working principles of windmills in real-life as they have not directly encountered resulting in students misunderstood the word problem. This is consistent with the interview result with students (SMA) who said: "I answered based on the guidance provided in the question". Thus, it can be concluded that students cannot understand the matter related to the story graph well. The correct answer based in the explanation of the problem should be option B.

\section{The Factors Influencing Students' Mathematical Representation}

There are few factors influencing students' mathematical representation errors in solving word problem related to graph. Based on the interview results of the students and teacher, it can be concluded that:

First, Students are rarely getting exposed to the problems demanding representation (including visual, symbolic, and verbal representation). It is evidenced from the interview results of one of the students (HR) who said that: "teachers should provide more various problems; not being in a hurry in completing the materials which results in many students do not understand the materials explained".

Second, The current text books include non-routine problems demanding problem solving skills. However, teachers do not discuss the solution in the class and therefore students are not able to solve the problems given in the test. This is in line with the interview results with the one of the students (LA) who mentioned that: "the problems given in the test is harder as we are not get used to solving them, teachers do not discuss the hard problems in the textbook in the teaching and learning process, it is usually given as home works". Furthermore, students are not used to solve problems similar to PISA context problems. The graph problems they often solve are the problems requiring understanding only which are available in the textbook. This is mentioned by one of the students (FR), "I am having difficulty in understanding problems related to graph as I have not encountered the test problems in the classroom".

Third, Students are not used to solve word-problems. Students are having difficulty in reading the problems leading to misinterpretation, understanding unfamiliar language, identifying the meaning of the problem and retelling using their own language; students lacking ability in interpreting sentences into mathematical models, and lack understanding of concepts results in students having difficulty in determining the formula/strategy to be used. This is in line with the interview results of one of the students (FAM) who mentioned that: "I misunderstood some problems related to graph, 


\section{Jurnal Riset Pendidikan Matematika, 5 (1), 2018 - 104}

Rahmah Johar, Khairiyah Rahma Lubis

this may be happen as I am not used to solve mathematics word problem".

Fouth, Teachers have time constraint in teaching. This is mentioned by one of the teachers $(\mathrm{AD})$, "the materials to be covered are too broad yet the teaching time is limited. Therefore, I do not have enough time to provide problems outside the text books; I hope students can learn about it outside the classroom". Teachers agreed that the problems tested by the researchers have never been given to the students in the classroom.

Based on the results of students' answers and interviews with students and teachers, it can be concluded that there are many students committed representation errors including visual, symbolic and verbal representation. This is in line with results of the study conducted by Suryowati (2015) reported that many students have not understood how to represent the reallife problem into mathematics problem. Students have difficulty in understanding the word problem because students are still confused and not able to interpret the sentences presented. The results of this study are in line with the research conducted by Sepeng \& Sigola (2013) stated that the errors exhibited by learners in the solution of word problems appeared to be as the result of lack of understanding of mathematical vocabulary used in a problem statement. In addition, the results of (Huda \& Angel, 2013) also concluded that student' difficulties in understanding the story is to understand the meaning of the words in the question provided.

Table 2 indicated that the highest percentage of representation errors is in solving problem $6(77.78 \%)$, in which the problem is presented in visual representation and students are asked to determine the other visual representation. This kind of representation change is rarely found in real-life and even never found in Indonesian textbooks. This is in line with Leinhardt, Zaslavsky, \& Stein (1990) who argued that there are small number of pages in the mathematics textbook provided graph task, and those available in the textbook are usually related to the introduction of coordinate system and early algebra, so that there is lack of discussion of graph tasks. In addition, Bunawan et al. (2015) and Mustain (2015) found that students cannot read the graph well.

The second highest percentage of representation error is in solving problem $8(69.44 \%)$. This problem involves graph connection to science phenomenon, namely the wind speed. If students do not understand that the wind speed is never 0 , students will end up choose option $\mathrm{D}$ instead of the correct answer (C). In PISA, this type of problem is classified as connection task demanding integration of mathematics and other subjects. This agrees with Sugiman (2008) who argued that the connection ability of Indonesia students is lacking. In addition, Linto, Elniati, \& Rizal (2012) also found that when students are asked to solve connection problem, they usually have difficulty in connecting the material learned and the prerequisite materials they have mastered.

The third highest percentage of students' representation errors is for the problem involving changing visual to symbolic representation in problem $2(50 \%)$. This means that students still made mistakes in interpreting the graph description in the word problem resulting in incorrect numeric calculation.

The fourth highest percentage of students' representation errors is hard to determine as the percentage from four problems related to changing visual to verbal representation (the first, third, fourth and fifth problem) are all around $10 \%$, except for problem 5 (41.67\%). This indicated that creating visual representation from contextual problem is not hard for students if the problem does not involve connection. Problem 5 is related to connection requiring students to think about distance and speed. Most students determine the distance solely based on the number of the grids on the $\mathrm{x}$ axis, whereas it should be influenced by time and speed.

Similar trend occurs for two problems involving changing verbal to visual representation (problem 7 and 8). Despite these problems having similar demands, the percentage of errors is different. The percentage of representation errors for problem 7 is $5.55 \%$ while it is $69.44 \%$ for problem 8 . This means that their representation ability is different due to the different complexity of the problems. Problem 7 only requires students to represent the situation of ideal place to build the windmill, while problem 8 demands connection between mathematics and physics in the context of windmills working principles (more complex). This indicated that students are not accustomed to solve the problems with higher complexity. The findings of research conducted by Iryanti (2010) showed that approximately $57 \%$ of the duration of mathematics lesson in Indonesia is spent to discuss the problems with low complexity and only about $3 \%$ of the allocated time spent to 
solve higher complexity problems. It is not surprising that the ability of Indonesian students at international level is low. These results are in accordance with the results of Shah \& Hoeffner (2002), Kali (2005), and Kilic et al. (2012) who revealed that students' abilities to read, interpret, understand and solve problems in the form of graphs are lacking.

\section{CONCLUSION}

Representation errors are not only influenced by the types of representation but also the complexity of the problems. This means that the problems with similar representation may result in different percentage of errors as a result of the different complexity of the problems. The data analysis of the test and interview results reveal that the highest representation errors occurred for the problem involving changing visual to another visual representation; followed by the problem involving changing verbal to another visual representation with different complexity; next is for the problem related to changing visual to symbolic representation; followed by the problem related to changing visual to verbal representation with different complexity. In general, the high percentage of students' representation errors is due to the fact that students are not accustomed to the problems requiring representation, students are not accustomed to solve problems with PISA contexts, students are not used to solve word problems and time constraints for teachers to teach non-routine problems.

\section{REFERENCES}

Adams, T. L. (2003). Reading mathematics: More than words can say. The Reading Teacher, 56(8), 786-795. https://doi.org/10.2307/20205297

Ahmad, A., \& Nawawi, M. (2010). Visual representations in mathematical word problem solving among form four students in Malacca. Procedia - Social and Behavioral Sciences, 8, 356-361. https://doi.org/10.1016/J.SBSPRO.2010.1 2.050

Alhadad, S. F. (2010). Meningkatkan kemampuan representasi multipel matematis, pemecahan masalah matematis, dan self esteem siswa SMP melalui pembelajaran dengan pendekatan open ended. Universitas Pendidikan Indonesia.
Bunawan, W., Setiawan, A., Rusli, A., \& Nahadi, N. (2015). Penilaian pemahaman representasi grafik materi optika geometri menggunakan tes diagnostik. Jurnal Cakrawala Pendidikan, XXXIV(2), 257267.

https://doi.org/10.21831/cp.v2i2.4830

Cai, J., Lane, S., \& Jakabcsin, M. S. (1996). The role of open-ended tasks and holistic scoring rubrics: Assessing students' mathematical reasoning and communication. In Communication in Mathematics, K-12 and Beyond (pp. 137145). Reston, VA: Academic Press New York.

Cresswell, J. (2016). Research design: Pendekatan metode kualitatif, kuantitatif, dan campuran (Edisi 4). Yogyakarta: Pustaka Pelajar.

Departemen Pendidikan Nasional. (2007). Kajian kebijakan kurikulum mata pelajaran matematika. Jakarta: Badan Penelitian dan Pengembangan Pusat Kurikulum.

Dewi, S. K., Suarjana, I. M., \& Sumantri, M. (2014). Penerapan model polya untuk meningkatkan hasil belajar dalam memecahkan soal cerita matematika siswa kelas V. MIMBAR PGSD Undiksha, 2(1). Retrieved from https://ejournal.undiksha.ac.id/index.php/J JPGSD/article/view/2057

Enu, J., Agyman, O. K., \& Nkum, D. (2015). Factors influencing students' mathematics performance in some selected colleges of education in Ghana. International Journal of Education Learning and Development, 3(3), 68-74. Retrieved from http://www.eajournals.org/wpcontent/uploads/Factors-InfluencingStudents----Mathematics-Performance-InSome-Selected-Colleges-Of-EducationIn-Ghana.pdf

Gegbe, B., \& .J.M, K. (2015). Factors contributing to students poor performance in mathematics at West African senior school certification examination (A case study: Kenema City, Eastern Province Sierra Leone). International Journal of Engineering Research and General Science, 3(2), 1040-1055. Retrieved from http://ijergs.org

Goldin, G. (2002). Representation in 


\section{Jurnal Riset Pendidikan Matematika, 5 (1), 2018 - 106}

Rahmah Johar, Khairiyah Rahma Lubis

mathematical learning and problem solving. In Handbook of International Research In Mathematics Education, Lawrence Erlbaum (pp. 197-218).

Graciella, M., \& Suwangsih, E. (2016). Penerapan pendekatan matematika realistik untuk meningkatkan kemampuan representasi matematis siswa. Metodik Didaktik: Jurnal Pendidikan Ke-SD-An, 10(2). Retrieved from http://ejournal.upi.edu/index.php/Metodik Didaktik/article/view/3180

Huda, N., \& Angel, G. K. (2013). The analysis of students' difficulties based on the ability on understanding and solving word problem of cube and cuboid content in the 8th grade SMPN 30 Muaro Jambi. In Prosiding Semirata FMIPA Universitas Lampung. $\quad$ Lampung: Universitas Lampung.

Iryanti, P. (2010). Potret pengajaran matematika SMP kelas 8 di Indonesia. Jurnal Edukasi Matematika, 1(2), 108-115.

Kali, H. D. (2005). First-year University Biology student's difficulties with graphing skill. University of the Witwatersrand Johanesburg.

Kar, T., Işık, A., Öçal, M. F., Çiltaş, A., Güler, G., \& Işık, C. (2011). Prospective mathematics teachers abilities' to construct relations between the different representations of series with complex terms. Procedia-Social and Behavioral Sciences, 15, 356-360.

Kilic, D., Sezen, N., \& Sari, M. (2012). A study of pre-service science teacher's graphing skills. Procedia - Social and Behavioral Sciences, 46, 2937-2941. https://doi.org/10.1016/J.SBSPRO.2012.0 5.593

Knuth, R. A., \& Jones, B. F. (1991). What does research say about mathematics?

Legi, Y. M. (2009). Kemampuan representasi matematis siswa kelas IV SD melalui pendidikan matematika realistik pada konsep pecahan dan konsep pecahan senilai. Universitas Negeri Malang.

Leinhardt, G., Zaslavsky, O., \& Stein, M. K. (1990). Functions, graphs, and graphing: Tasks, learning, and teaching. Review of Educational Research, 60(1), 1-64. https://doi.org/10.3102/003465430600010 01
Linto, R. L., Elniati, S., \& Rizal, Y. (2012). Kemampuan koneksi matematis dan metode pembelajaran quantum teaching dengan peta pikiran. Jurnal Pendidikan Matematika, 1(1), 83-87. Retrieved from http://ejournal.unp.ac.id/students/index.ph $\mathrm{p} / \mathrm{pmat} /$ article/view/1176

Mbugua, Z. K., Kibet, K., Muthaa, G. M., \& Nkonke, G. R. (2012). Factors contributing to students' poor performance in mathematics at Kenya certificate of secondary education in Kenya: A case of Baringo County, Kenya. American International Journal of Contemporary Research, 2(6), 87-91. Retrieved from https://www.aijcrnet.com/journals/Vol_2_ No_6_June_2012/11.pdf

Mustain, I. (2015). Kemampuan membaca dan interpretasi grafik dan data: Studi kasus pada siswa kelas 8 SMPN. Scientiae Educatia: Jurnal Pendidikan Sains, 4(2). https://doi.org/10.24235/sc.educatia.v4i2. 493

National Council of Teacher Mathematics. (2000). Prinsiples and standards for school mathematics. Reston, VA: NCTM.

OECD. (2003). The PISA 2003 assesment framework-Mathematics, reading, science and problem solving knowledge and skills. Paris: Organisation for Economic Co-operation and Development. Retrieved from

http://www.oecd.org/edu/school/program meforinternationalstudentassessmentpisa/ pisa2003assessmentframeworkmathemati csreadingscienceandproblemsolvingknowl edgeandskills-publications2003.htm

OECD. (2009). Take the test. Sample questions from OECD's PISA assessments. Paris: OECD.

Palm, T. (2009). Theory of authentic task situations. Sense Publishers. Retrieved from http://umu.divaportal.org/smash/record.jsf?language $=\mathrm{sv}$ \&pid=diva2\%3A291640\&dswid $=7032$

Rosyidi, A. H. (2011). The analysis of the students' error at second grade students' of MTs Alkhoiriyah in solving word problem about linear equation with two variables. Universitas Negeri Surabaya.

Sari, R. H. N., \& Wijaya, A. (2017). Mathematical literacy of senior high 
school students in Yogyakarta. Jurnal Riset Pendidikan Matematika, 4(1), 100. https://doi.org/10.21831/jrpm.v4i1.10649

Sepeng, P., \& Sigola, S. (2013). Making sense of errors made by learners in mathematical word problem solving. Mediterranean Journal of Social Sciences, 4(13), 325-333. Retrieved from http://www.mcser.org/journal/index.php/ mjss/article/view/1520

Shah, P., \& Hoeffner, J. (2002). Review of graph comprehension research: Implications for instruction. Educational Psychology Review, 14(1), 47-69. https://doi.org/10.1023/A:1013180410169

Sugiman, S. (2008). Koneksi matematik dalam pembelajaran matematika di sekolah menengah pertama. Pythagoras: Jurnal Pendidikan Matematika, 4(1). https://doi.org/10.21831/PG.V4I1.687

Suryowati, E. (2015). Kesalahan siswa sekolah dasar dalam merepresentasikan pecahan pada garis bilangan. AKSIOMA Journal of Mathematics Education, 4(1). https://doi.org/10.24127/ajpm.v4i1.67

Wardhani, S., \& Rumiati. (2011). Instrumen penilaian hasil belajar matematika SMP: Belajar dari PISA dan TIMSS. Yogyakarta. Retrieved from http://p4tkmatematika.org/file/Bermutu 2011/SMP/4.INSTRUMEN PENILAIAN HASIL BELAJAR MATEMATIKA .....pdf

Wijaya, A., van den Heuvel-Panhuizen, M., Doorman, M., \& Robitzsch, A. (2014). Difficulties in solving context-based PISA mathematics tasks: An analysis of students' errors. The Mathematics Enthusiast, 11(3). Retrieved from http://scholarworks.umt.edu/tme/vol11/iss $3 / 8$ 